\title{
Geç Dönem Wittgenstein Felsefesinde Gramer Kavramı ve Dilin Otonomisi
}

\section{Umut Morkoç}

Özet: Wittgenstein felsefesinin merkezi temasını anlam kavramı oluşturur. Tractatus Logico-Philosophicus'ta anlamı dil dışı bir gerçeklikten hareketle tanımlayan Wittgenstein, felsefesinin geç döneminde anlamı dilin kullanımıyla tanımlar. Wittgenstein'ın, “'anlam nedir?' sorusunun yeryüzüne inmesi” olarak tanımladığı bu geçiş temel olarak, gramer kavramına dayanmaktadır. Dilin otonomisi, bu dönüşümün önemli bir sonucudur. Bu çalışmada, Wittgenstein'ın gramer kavramı ve bu kavramın bir sonucu olarak dilin otonomisi kavrayışı açık kılınmaya çalışılacaktır. Bunun için öncelikle gramer kavramının Wittgenstein'ın geç dönem felsefesindeki işlevi belirlenecek daha sonra buradan hareketle dilin otonomisinin ne anlama geldiği açıklanacaktır.

Anahtar Kelimeler: Wittgenstein, anlam, gramer, dilin otonomisi

\section{The Concept of Grammar and Autonomy of Language in the Philosophy of Late Wittgenstein}

\begin{abstract}
The concept of 'meaning' constitutes the central theme of Wittgenstein's philosophy. Wittgenstein, who characterizes meaning on the basis of an extralinguistic reality in Tractatus Logico-Philosophicus, in the later period of his philosophy, characterizes meaning by use. This transition, which Wittgenstein calls "bring the question 'what is meaning' down to earth", rests on his concept of grammar. Autonomy of language is an important consequence of this transition. In this paper Wittgenstein's conception of grammar and autonomy of language which results from this conception will be explicated. To this end first the role of the concept of grammar in Wittgenstein's philosophy will be clarified and then on the basis of this what is meant by the autonomy of language will be explained.
\end{abstract} Keywords: Wittgenstein, meaning, grammar, autonomy of language

\section{Giriş}

Dili felsefenin odağına yerleştiren felsefe geleneğinin köşe taşlarından biri olan Tractatus Logico-Philosophicus'un temel iddiası, dilin dünyanın resmi olduğudur. Resim kuramı olarak adlandırılan bu sava dair ilk işareti, Wittgenstein'ın Avusturya Birinci Ordusuna bağlı olarak katıldığ 1 Birinci

Morkoç, Umut. (2016). Geç Dönem Wittgenstein Felsefesinde Gramer Kavramı ve Dilin Otonomisi. Kilikya Felsefe Dergisi 2. ss. 93-111. 
Dünya Savaşı'nda cephede tuttuğu notlarda buluruz. Daha sonra TLP içerisinde sistemli bir bütün olarak ifade edilecek olan düşüncelerin ilk örneklerini oluşturacak olan Defterler'in 29.09.1914 tarihli notunda Wittgenstein,

"[Ö]nermede, dünya, deneysel olarak bir araya getirilir. (Paris'teki mahkeme salonunda bir otomobil kazasının kuklalar vb. aracilığıyla temsil edilmesi gibi)" der (Defterler, s. 17).

$\mathrm{Bu}$ yaklaşıma göre dili oluşturan önermeler mümkün dünyanın bir resmini sunmaktadırlar. Wittgenstein bu resmetme sürecinin, dil ile dünyanın ortak bir mantıksal biçime sahip olmasıyla mümkün olduğunu iddia eder. Bu anlayışa göre bir resim olarak dil, anlamını, dünyada bulmaktadır. Daha açık bir ifadeyle, bir önermenin anlamını, karşılığ1 olduğu olgu durumu oluşturmaktadır. Ancak burada gözden kaçırılmaması gereken şey, Wittgenstein'ın olgu olarak adlandırdığının dünyada bilfiil var olan gerçeklikler -kendi tabiriyle 'şey'ler-değil, mantıksal uzamdaki tüm olası olgular olduğudur (TLP, 1.1, 1.13). Böylece Wittgenstein'a göre dünya, olguların toplamıdır. Dil, aynı mantıksal biçimi paylaşması sebebiyle dünyanın bir resmini sunabilmekte ve böylece referansını dünyadan almaktadır. Dünyayı resmeden dil ve dolayısıyla bu dilin dünyayı resmedecek olan sembolleri, mantıksal sentaksın kurallarına göre tasarlanmalıdırlar. Mantıksal sentaksın kurallarına uymayan bir dil herhangi bir olgunun resmini sunamayacağı için saçma olacaktır. Saçma olmayan yani mantıksal sentaks kurallarına uygun bir ifade ise resmi olduğu gerçekliğe uygunluğuna göre doğru veya yanlış değerini alır $(T L P, 2.21)$. Burada değinmeden geçemeyeceğimiz bir üçüncü durum ise herhangi bir olgu durumuna işaret etmeyen ancak olguların mantıksal biçimini yani mantıksal sentaksın kurallarından söz eden ifadelerdir, Wittgenstein bu ifadeleri anlamdan yoksun önermeler olarak niteler (TLP, $4.461,5.1362,5.5351)$. Dil ile dünya arasında varsayılan mantıksal özdeşliğe dayalı bu anlam kuramıla Wittgenstein, peşine düştügü bütün felsefe sorularının yanıtını verdiğini düşünür ${ }^{1}$ ve 1929 yılında düşüncelerinde çok köklü dönüşümler meydana gelene kadar büyük ölçüde felsefeden uzak durur.

Wittgenstein felsefesinin iki farklı dönemde anılmasına yol açan

\footnotetext{
Wittgenstein 13.03.1919 yılında Russell’a yazdığı mektupta şöyle der: “Sonunda sorunlarımızı çözdüğüme inanıyorum. Kulağa küstahça gelebilir ama buna inanmaktan kendimi alamiyorum." (Aktaran: Monk, 2005, s. 240).
} 
kırılmalar özellikle 1920'li yılların ikinci yarısında Viyana Çevresi düşünürleriyle girdiği ilişkiler ve bu ilişkilerin sağladığı entelektüel karşılaşmalarla ilişkilendirilebilir. Ancak bu kırılma açısından bir tarihi, miat olarak anmak gerekirse bu tarih 18.01.1929 olacaktır. Wittgenstein bu tarihte sürekli kalma planıla Cambridge'e gider. Sürekli kalmak niyetindedir; zira felsefeyi sonlandırmasına yol açan yanıtları konusunda aklında yeni soru işaretleri vardır. Bu soru işaretlerinden belki de en önemlisi, resim kuramının omurgasını oluşturan mantıksal biçime yönelik olanıdır. Resim ile resmedilen yani dil ile dünya arasındaki ilişkiyi mümkün kılan mantıksal biçim ortaklığı artık Wittgenstein açısından bir sorun teşkil etmektedir². Bu yeni döneminde Wittgenstein dil ile dünyanın aynı mantıksal biçimi paylaşmaları fikrinden hareket eden resim kuramından vazgeçer. Anlam artık, dilin resmettiği dünyada değil dilin kullanılışındadır; dolayısıyla dilin anlamlı olması için mantıksal sentaks kurallarını değil dili ne şekilde kullanacağımızı belirleyen kuralları takip etmesi gerekmektedir. Dile dair bu kuralların belirleyicisi ise dilin içerisinde kullanıldığ biçimidir. Bir ifadenin anlamını artık dünyadaki karşılığı değil, o ifadenin ne şekilde kullanılacağını belirleyen kurallar bütünü (gramer) oluşturur. Böylelikle dili mantıksal sentaks kurallarıyla kuran yaklaşımdan, dili kullanıyor olmayı çok boyutlu ve kurallar tarafından şekillendirilen bir etkinlik olarak belirleyen anlayışa geçilmiş olur. Bir dil oyunu içerisinde sembollerin ne şekilde kullanılacağını belirleyen gramer kuralları, bu işlevleri itibariyle $T L P^{\prime}$ daki mantıksal sentaks kurallarına benzerler; ancak gramerin kapsamı çok daha geniştir. Bu geçiş sürecinde meydana gelen bir diğer önemli değişiklik de kuralların etki alanına ilişkindir. Mantıksal sentaks kuralları her zaman ve herkes için geçerli, evrensel kurallardı;

${ }^{2}$ Wittgenstein mantıksal biçim anlayışında meydana gelen bu değişimi öğrencisi Norman Malcolm'a ünlü İtalyan ekonomist Piero Sraffa ile yaptığı ilginç bir sohbet üzerinden aktarır. Malcolm'ın aktardığına göre, Wittgenstein ve Sraffa yaptıkları bir tren yolculuğu sırasında mantıksal biçim üzerine konuşmaktadırlar ve Wittgenstein bir önerme ile bu önermenin resmettiği gerçekliğin aynı mantıksal biçimi paylaşmak zorunda oldukları yönünde ısrar etmektedir. Wittgenstein'ın bu ısrarı üzerine Sraffa, parmak uçlarıyla çenesine hafifçe dokunur ve bu hareketin mantıksal biçiminin ne olduğunu sorar. Napolilere özgü olan ve hoşnutsuzluk bildiren bu hareketin, dil ve dilin içerisinde şekillendiği koşullar -yani yaşam biçimi- arasındaki ilişkiye ikinci döneminde temel bir önem atfeden Wittgenstein üzerinde önemli bir etkisi olduğu bir anekdot olarak anlatılmaktadır (Malcolm, 1984, ss.5354). Kuşkusuz ki, Sraffa'nın sergilediği jestin Wittgenstein'ın düşünce dünyasında meydana gelen dönüşüm açısından bir evraka anı olduğunu iddia etmek gerçekçi olmayacaktır; ancak, eserlerinde isimlere atıfta bulunma konusunda oldukça eli sıkı davranan Wittgenstein'ın $F S^{\prime}$ ın 'önsöz'ünde Sraffa'yı "kitabındaki fikirlerinin en verimlilerini borçlu olduğu kişi" olarak zikretmesi Sraffa'yla yaptıkları tartışmaların mantıksal biçim konusundaki fikirlerinin değişmesinde etkili olduğunu kanaatini güçlendirmektedir. 
ancak gramer kuralları belirli bir dil oyunu için belirli bir zamanda geçerli olan kurallardır. Başka bir ifadeyle, mantıksal sentaks kuralları sadece bir temsil tarzının kurallarını belirlerken, gramer her bir dil oyununun kendine has kurallarla var olduğunu söylemekte ve dil oyunlarının kurallarını kendilerine özgü kılmaktadır. Anlam artık referansını dil dışı bir dünyada değil, bilakis dilin kendi kullanımında bulur. Böylelikle bir resim olarak anlamını, resmettiği şeyden alan dil anlayışından, anlamını kendi kullanımından alan otonom bir dil anlayışına geçilmiş olur.

\section{Gramer}

Wittgenstein'ın geç dönem felsefesinde gramer kavramını "sözcüklerin ne şekilde kullanılacağını gösteren kurallar" (PG, I, 133) bütünü olarak tanımlayabiliriz. Bu anlayışa göre bir ifadenin anlamını onun ne şekilde kullanıldığı belirlemektedir. Buradan hareketle gramerin Wittgenstein' in geç dönem felsefesindeki 'anlam' kavrayışı açısından oldukça kritik bir yeri olduğunu söyleyebiliriz. Gramer kuralları, kullanımı belirlemeleri suretiyle anlamı belirlemiş olurlar, başka bir ifadeyle onu inşa ederler. Dolayısıyla Wittgenstein'da gramerin ne anlama geldiğini ortaya koyabilmek için kural ve anlam kavramları ekseninde bir soruşturma yürütmek gerekir.

Wittgenstein'a göre dil ile gramer arasındaki ilişki oyun ile onun kuralları arasındaki ilişkiye benzer ( $P G, \mathrm{I}, 23)$. Kurallar bir oyun açısından ne şekilde kurucu nitelik taşıyorlarsa, gramer de dil için benzer bir kurucu nitelik taşımaktadır. Nasıl ki kuralları olmazsa ortada bir oyundan söz edemezsek, kuralların olmadığ bir durumda da bir dilden söz etmek mümkündeğildir (WLI, s.48). Belirli sayıda ve belirlidüzendeoluşturulmuş kareler üzerinde oynanması, belirli sayıda ve belirli hareket yeteneklerine sahip taşlarla oynanması, oyunun taraflarının hamlelerini sırayla yapıyor olmaları v.s. olmadan bir satranç oyunundan söz etmek nasıl ki mümkün değilse; bir anlaşma pratiği olarak dil de ancak kendini var eden kurallar aracılığıyla mümkün olabilmektedir. Benzer bir şekilde, oyun içerisinde bir hamlenin uygunluğu nasıl ki kurallara referansla belirleniyorsa, dil içinde de bir kullanımın uygunluğunun kıstası gramer kurallarıdırlar. Uygunluk ile hangi hamle yapılırsa bunun oyunun kazanılması için doğru bir hamle olacağı değil; hangi hamlenin ya da hamlelerin yapılmasının mevcut kurallar dahilinde olanaklı olduğu ifade edilmektedir. Burada işaret edilen, kuralların dil için de oyun için de sınırları tayin eden bir nitelik taşıyor olmasıdır. Bu anlamda nasıl ki kurallar, ihlal ettiğimizde 
oyunun dışında kaldığımız birer emir niteliği taşıyorsa; dil için de gramer, ihlal edildiğinde oyunun dışında kaldığımız bir buyruk niteliğindedir. Böylelikle gramerin dil içerisindeki tüm mümkün kullanımların sınırlarını tayin ettiğini söyleyebiliriz. Ancak gramerin bir dil oyunundaki işlevi sadece bu dil oyunundaki kullanımların sınırlarını belirlemesinden ibaret değildir. Gramer aynı zamanda neyin bir ifadenin uygulaması olarak kabul edilebileceğini de gösterir. Örnek verecek olursak, 'sandalye'nin grameri sandalyenin üstüne oturulacak şey olduğunu söylemekle kalmaz; ne tür bir fenomenin 'sandalyeye oturmak' olarak kabul edileceğini de söyler. Başka bir ifadeyle gramer, sadece bir sandalyeye oturma eylemini dillendirmez; sandalyeye oturmanın nasıl bir şey olduğunu da dillendirmiş olur. Bir nesneyi her neyse o yapan şeyin yani anlamının onun kullanılışı olduğunu göz önüne alacak olursak sandalyenin kullanılışını belirleyen kurallar yani sandalyenin grameri, onun kurucusudur. Böylece gramatik kurallar dil oyunu içerisindeki kullanışları betimleyen ve onlara anlam veren kurallardır (PG, I, 62-64; KÜ, 61-62).

Bir dilin grameri o dili var eden gramatik kuralların oluşturduğu bir sistemdir ve bir önermenin anlamı onun içinde yer aldığı gramatik sistem tarafından belirlenir, bu sistem mevcut önermenin diğer önermelerle olan ilişkisini de belirler. Tıpkı öncülü olarak kabul edeceğimiz mantıksal sentaks gibi gramerin de dilin genel işleyişi açısından kurucu bir niteliği vardır. Ancak mantıksal sentakstan farklı olarak gramer, evrensel bir yapı taşımaz. Farklı dillerin farklı gramerleri olabilir, gramer, kurallarını oluşturduğu dil içerisinde ifadelerin anlamlarını ve birbirleriyle ilişkilerini belirler.

Wittgenstein'da gramer kullarının öne çıkan bir diğer temel özelliği de doğruluk ya da yanlışlık iddiasındaki önermeleri barındıran dil oyunları içerisinde üstlendikleri işlevdir (Foster, 2004, s.9; Baker ve Hacker, 2009, s. 61). Hatırlanacağ gibi, erken döneminde Wittgenstein en basit ifadesiyle, resim ile resmedilen arasındaki tekabüliyete dayanan (TLP, 4.021) bir doğruluk anlayışını benimsemekteydi; geç döneminde ise gramer, temel kurallarını oluşturduğu dil oyununun barındırdığı ifadelerin doğruluk ya da yanlışlığının kendisine referansla belirlendiği kuralları oluşturmaktadır. Bu sebeple doğruluk ya da yanlışlık iddiasındaki dil oyunlarının gramer kuralları özel bir yere sahiptir. Bu tip dil oyunlarının doğruluk ya da yanlışlık değeri alabilecek empirik ya da olgusal iddiaları ve bu iddiaların kendilerine referansla doğru mu yanlış mı olduklarına karar verdiğimiz gramatik bileşenleri vardır. Burada dil oyununun empirik ya da olgusal 
bileşenleri adeta bir nehrin akan su kısmını oluştururken, bu suyun nasıl ve nereye akacağı konusunda belirleyici niteliğe sahip olan nehir yatağ1 dil oyununun gramatik boyutunu oluşturur (KÜ, 97, 98). Dil oyunu içerisinde gramere bu gücü atfeden şey ise taşıdığı zorunluluktur.

Nedensel ve deneysel olmayan daha sikı, daha sert hatta kaskatı bağıntı daima bir gramer bağıntısıdır (RFM, I, 128).

Dil oyunun kurallarını ifade eden gramer önermelerini; doğadaki fenomenleri ya da olguları dile getiren deneyim önermelerinden ( $F S$, 295) ve kimi zaman gramer önermeleri gibi kimi zaman deneyim önermeleri gibi görünen ve felsefeyi sıklıkla meşgul eden kurgusal (Wittgenstein'ın tabiriyle 'sı̆̆ gramer') önermelerden (FS, 307, 664) ayıran, gramer önermelerinin taşıdığ zorunluluktur.

Sıradan bir deneyim önermesi ile bir gramer önermesi arasındaki fark göz önüne alındığında gramerin kendine has bu niteliği daha da anlaşılır olacaktır. Gramer önermesi ile deneyim önermesinin farkı; bir oyunun kurallarıyla, bu oyunun kuralları uyarınca hareket etmek arasındaki fark gibidir. Gramer önermeleri oyunun o oyun olarak var olmasını sağlayan kurallar oldukları için zorunluluk taşırlar, başka bir ifadeyle, bu kurallar olmazsa ortada bir oyun olmayacaktır. Gramer önermesi temel olarak, bir kuralı ifade etmek üzere kullanılır. Bu anlamda gramer bizim temsil biçimimizi belirler $(F S, 50)$. Bu ifadede biçime yapılan vurgu gramerin yukarıda bahsettiğimiz sınır koyucu niteliğini vurgulamaktadır. Böylece gramer bir temsil olarak dil oyununun biçimini belirlemiş olur. Ancak burada gözden kaçırılmaması gereken, Wittgenstein'ın sözünü ettiği 'temsil'in TLP'daki gibi olgular dünyasının bir resmedilişi olmamasıdır. Temsil artık, gramer kurallarının belirlediği bir dünya-resmi'nin dile gelişidir. $^{3}$

\section{Gramer Önermeleri:}

Gramerin ve bu grameri dile getiren önermelerin ne olduğunu ortaya

3 Wittgenstein temsil kavramını (İng. representation, Alm. darstellung) geç döneminde birçok kez kullanır (bkz. FS, 50; 122; 295; 366; 397; 522; 649; s.206; s.216; s.218; s.233). Bu kullanımların çoğu kavramı merkeze almayan kullanımlardır, dolayısıyla kavramın gündelik kullanımına işaret ederler; ancak özellikle $F S, 50$ ve 122 temsil kavramının sunmaya çalıştığımız kullanımına ilişkin detaylar içermektedir. $(F S, 50)$ 'de bir dil oyunu içerisinde yer alan unsurları o dil oyununa ait birer "temsil aracı" olarak ve temsili mümkün kılan paradigmayı temsil tarzı olarak niteleyen Wittgenstein, $(F S, 122)$ 'de şöyle der: "Bir bakışta görülür kılan bir temsil kavramı [perspicious representation] bizim için temel bir anlam ve önem taşır. Temsil biçimimizi, şeyleri ne şekilde gördüğümüz imler. (Bu bir 'Weltanschauung' [dünyaya bakış tarzı, dünya görüşü, dünya resmi] mudur?)". 
koyduktan sonra Wittgenstein'ın verdiği örneklerden hareketle üç tür gramer önermesinden söz edebiliriz. Bir gramer önermesi, anlama ve dolayısıyla kullanıma direk bağlıdır. Buradan hareketle bir ifadenin bir dil oyunu içerisindeki kullanımını betimlemek suretiyle anlamını dile getiren önermeleri birinci tür gramer ifadeleri olarak adlandırabiliriz. Bir ifadenin anlamin dile getirirken onun kullanımına dair kurallar dile getiririz ve bu ifadeler böylece gramer önermeleri olarak adlandırılabilirler. Wittgenstein Matematiğin Temelleri Üzerine Dersler'de gramer ifadesine şöyle bir örnek verir: " 'Bir kanepe bir sandalyeden daha uzundur' - gramatiktir" (LFM, s.250). Wittgenstein bu ifadeyi gramatik olarak adlandırır çünkü bu ifadeyle 'kanepe'nin anlamına ve dolayısıyla kullanımına dair bir şeyden söz edilmektedir. Bir gramer önermesinin zorunluluğu onun kural koyuculuğuyla alakalıdır. Kuralın kendisi değerlendirme söz konusu olduğunda başvuru mercii olduğu için aksi düşünülebilir değildir, bu da bir gramer ifadesine zorunluluk katar. Bir kural cümlesi olarak 'bir kanepe bir sandalyeden daha uzundur' cümlesi, kanepenin anlamina dair bir kuralı dile getirdiği için bir gramer cümlesidir ve aksini zihnimizde canlandıramayız. Eğer 'kanepe'nin anlamına dair bu kuralı kabul edip, sandalyeden daha küçük bir kanepe hayal edebiliyorsak hayal ettiğimiz şey kanepe olmaz; zira kanepe onu her ne ise o yapan kurallar gereği sandalyeden daha uzun olan bir şeydir. Tipkı satranç oynarken atımı bir kare ileri sürüp bu benim hamlemdir dediğimde, oynadığım oyunun artık satranç olmaması gibi. " 'Aksini canlandıramam zihnimde', burada tabii ki imgeleme gücüm yetmez demek değildir. Bu sözlerle, biçimiyle bir deneyim tümcesiymiş gibi görünen ama gerçekte bir gramer tümcesi olan bir şeye karşı koruruz kendimizi" (FS, 251). Wittgenstein, bir ifadenin kullanımını dolayısıyla anlamını betimleyen gramer önermelerini çeşitli yerlerde örneklendirir":

"İki kitap aynı renkte" ibaresini kullanırız, ama pekala şunu da söyleyebilirdik: "bunlar aynı renkte olamaz, çünkü, her şeye karşın, bu kitap kendi rengine sahip, öteki kitap da kendi rengine." Bu da gramatik bir kural öne sürmek olurdu-sıradan kullanımımızla rastlantı eseri uyumlu olmayan bir kural (MKK, s. 63).

Wittgenstein bu örnekte 'aynı renk' ifadesinin kullanımına ve dolayısıyla onun anlamına dair bir gramer önermesi olduğunu söyler; ancak bu örneğin ayırt edici özelliği 'aynı renk' ifadesinin mevcut kullanımına (Wittgenstein'ın ifadesiyle, "sıradan kullanımımıza") aykırı bir gramer ifadesi olmasıdır. Buna rağmen bu ifadeyi sıradan bir deneyim ifadesinden ayırmak mümkündür. 'Aynı renk'te olmak ile mevcut örnekte

4 Wittgenstein'ın verdiği benzer gramer önermesi örnekleri için bkz. (FS, 247, 248, 574). 
betimlenen kuraldan hareketle masamdaki iki kırmızı kitabın aynı renkte olduğunu söylemek saçma olacaktır; zira 'aynı renk'te olmaya dair gramer önermesi bu durumun zihnimizde canlandırılmasını engeller. Bu tip gramer önermelerinin bir diğer temel özelliği de anlama dair bir açıklama sunmamaları, anlamı ifade eden kullanıma dair belli bir örneği betimliyor olmalarıdır:

Gramer bize dilin, amacını gerçekleştirmek için, insanlara falanca şekilde etki etmek için nasıl yapılanmış olması gerektiğini söylemez. İmlerin kullanımını, hiçbir şekilde açıklamayıp, betimler yalnızca (FS, 496).

İkincitürgramer ifadeleri ise matematikselönermelerdir. Wittgenstein " $2+2=4$ " önermesinin " 2 " hakkında olmadığını, bir kural koyduğunu ve bu anlamda bir gramer önermesi olduğunu söyler (LFM, s. 251). Bu önerme " $2+2$ " nin " 4 " ile yer değiştirebileceği kuralını betimlemektedir. Böylelikle bu önerme, bir dil oyununda " $2+2$ " nin " 4 " ile yer değiştirebileceği kuralını betimlemektedir. Benzer bir şekilde geometri de uzamsal ilişkiler hakkında konuşulabilmesinin kurallarını sağlar: “Uygulamalı geometri uzamsal nesneler hakkındaki cümlelerin grameridir" (PG, II, 17). Geometrinin önermeleri uzamsal ilişkilerin kurallarını belirler ve buradan hareketle uzamsal ilişkiler üzerine yapılacak bir konuşmanın sınırları belirlenmiş olur. Bir dairenin köşe sayısından bahsedemememiz geometrinin belirlediği sınırların dışına çıkmamız anlamına gelmektedir. Geometrinin bu gramatik işlevi bir üçgenin iç açılarını 185 derece ölçtüğümüzde bir yerde hata yaptığımızı bilmemizi sağlayan şeydir.

Üçüncü tür gramer ifadeleri ise gösterimsel tanımlardır. Glock, A Wittgenstein Dictionary'de (Bir Wittgenstein Sözlügüu) gösterimsel tanımlamanın üç unsuru olarak gösterimselden, gösterici işaretten ve örnekten bahseder: Gösterimsel, bahsedilen şey ne ise onu göstermek; gösterici işaret, bir şeyi bir işaret ile (ok, el işareti, v.s.) göstermek; örnek ise ifade edilmek istenenin örneklendirilmesi manasına gelmektedir (Glock,1996, s. 274). Bilindiği üzere Wittgenstein bu şekilde dil edinimini "Augustinusçu dil resmi" olarak adlandırıyor ve dil içerisinde bu tip bir işlevin olduğunu ancak dilin tümünün bu tip bir öğrenme pratiğinden ibaret olmadığını söylüyordu. Gösterimsel tanımlamalar tıpkı diğer gramer ifadeleri gibi kural koyucu bir niteliğe sahiptirler çünkü tıpkı diğer gramer önermeleri gibi bir ifadenin ne şekilde kullanılacağına dair kuralları belirlerler. Bu işlevlerini neyin ne yerine koyulabileceğine 
dair bir kural koyucu olmalarından kazanırlar. Kırmızıya dair bir gösterimsel tanımlama 'benim bisikletim şu renktir' gibi bir işaretten 'benim bisikletim kırmızıdır'a geçiş yapmamızı sağlayan kuralı verir (Glock,1996, s. 274). İşaret edilen örnek, ifadenin doğru kullanımına dair bir kuralı temsil etmektedir; dolayısıyla bu örnekten hareketle ifadenin yanlış kullanımlarını tespit etmek mümkündür. Bu işlevi nedeniyle gösterimsel tanımlamanın bir ifadenin uygun kullanımına dair kuralı belirlediği, böylelikle o ifadenin anlamı neyse ona işaret ettiği söylenebilir. Buradan hareketle gösterimsel tanımlamanın da gramatik bir işleve sahip olduğunu söyleyebiliriz.

\section{Gramer ve Gramatik Bir Sistem Olarak Dil}

“Dil nedir?" gibi bir soru, Wittgenstein'a göre anlamsız bir sorudur. Çünkü bu soruya yanıt vermeye çalışmak, zamanı ve mekânı aşan bir dil tanımının peşinde olmak demektir; oysaki Wittgenstein'a göre dil, şu an, burada olan ve sürekli değişen dinamik bir yapıdır. Bu sebeple dilin ne olduğuna dair soru, dilin özüne dair bir sorgulamayı içerdiği için yanıtlanamaz. Yapılabilecek olan sadece şu an, burada olanı sorgulamak daha doğrusu ona bakmaktır. Wittgenstein dilin elde edebileceğimiz bir özü olduğu fikrini reddeder, ona göre "öz bizden gizlidir" (FS, 92). Wittgenstein'a göre dil derken bahsettiğimiz şey tam olarak şudur: "Dil denen uzaysal ve zamansal görüngüden bahsediyoruz; uzam ve zaman dışı bir zırvadan değil" (FS, 108). Böylece geç dönem Wittgenstein için dilin ancak, dil oyunlarından oluşan dinamik bir ağ olduğunu söyleyebiliriz ve bu sebeple "dilin özü nedir?" gibi bir soru anlamsızdır. Wittgenstein'ın öze ilişkin bu reddiyesi, dili, üzerinde konuşamayacağımız bir kavram olarak ele almamıza yol açmamalıdır; zira bu reddiye temel olarak, dili ele alış tarzımıza ilişkin bir eleştiriyi içermektedir. Dil artık bir aile benzerliğ $i$ kavramı çerçevesinde değerlendirilmelidir $(F S, 108)^{5}$. Bu anlamda 'dil'den anlamamız gereken artık dil oyunudur çünkü Wittgenstein'a göre "dil ile dilin iç içe olduğu etkinlikler bütününe 'dil oyunu'” $(F S, 7)$ denir. Bu sebeple dil ile gramer arasındaki ilişki gramer ile dil oyunu arasındaki ilişki manasına gelmektedir. Peki, gramer kurallarıyla oluşturulan bu tarz bir sistem yani dil oyunu ne şekilde ortaya çıkmaktadır?

\footnotetext{
5 Çalışmanın kapsamını aşacağı kaygısıyla sadece adını zikretmekle yetindiğimiz "aile benzerliği " kavramı Wittgenstein'ın geç dönem felsefesi açısından oldukça merkezi bir kavramdır. Aile benzerliği ile Wittgenstein felsefi bir tutum olarak özcülüğe bir eleştiri sunmaktadır. Kavram, metinde kullandığımız bağlamda dil oyunu dediğimiz şeylerin hepsinin paylaşttğ̆ ortak bir özellik olmadığını, dil oyunlarının çeşitli benzerlikler yoluyla birbirleriyle-tıpkı akrabalık ilişkisi gibi- ilişkili olduğu ifade etmektedir.
} 
Wittgenstein dil oyunlarını birer etkinlik olarak tanımlar ve bir dil oyununa katılmak o oyunu oynamaya başlamak manasında gelmektedir. Dil oyunun bu şekilde bir faaliyet olarak tarif edilmesi dil oyunu ile yaşam arasında kurulan bir ilişkiyi ortaya koymaktadır. Bu sebeple burada sözünü ettiğimiz dil, gündelik anlamda anladığımız şekliyle sadece, "İnsanların düşündüklerini ve duyduklarını bildirmek için kelimelerle veya işaretlerle yaptıkları anlaşma, lisan, zeban"6 anlamına gelmemekte; çok daha kuşatıcı bir nitelik taşımaktadır. Wittgenstein $F S^{\prime}$ ın henüz başlarında bu çeşitliliği gösterebilmek için oldukça farklı ve çeşitli dil oyunu örnekleri verir ve bunları gözden geçirmeyi salık verir:

Emretmek ve emir uyarınca eylemde bulunmak-

Bir nesnenin görünüşünü ya da boyutlarını betimlemek-

Betime (çizime) dayanarak bir nesne üretmek-

Bir olayı bildirmek-

Bir olay hakkında tahminler yürütmek -

Bir hipotez ortaya atmak ve bunu sinamak-

Bir deneyin sonuçlarını tablo ve çizelgelerle sergilemek-

Bir öykü uydurmak; bunu okumak-

Tiyatro oyunu oynamak-

Tekerleme söylemek-

Bilmece yanitlamak-

Şaka yapmak; fikra anlatmak-

Uygulamalı aritmetik problemi çözmek-

Bir dilden diğerine çeviri yapmak - $(F S, 23)$.

Burada sunulan dil oyunu örnekleri de göstermektedir ki, geç dönem Wittgenstein için dil, insanların içerisine katılarak müdahil oldukları bir etkinliktir. Bir dili anlamak ise bu etkinliğin kurallarına vakıf olmak demektir. Wittgenstein bu durumu FS'da şöyle dile getirir: "Bir dili anlamak bir tekniğe hakim olmak" (FS, 199) demektir. Wittgenstein'ın burada teknik ifadesini kullanmasının gramer ve dil arasında kurulacak ilişki açısından özel bir önemi vardır. Teknik, yapılan şeye ilişkin izlenecek yolu, uygulanacak yöntemi ifade eder. Satranç oynamak ya da satranç oyununa dahil olmak o oyuna dair teknikten haberdar olmayı gerektirir. Hamle sırasının nasıl olacağını, satranç tahtasının düzenini, satranç taşlarının hareket kabiliyetlerini, oyunu kazanmak ve kaybetmenin ne olduğunu bilmeksizin satranç oynanmaz; zira bunlar satranca dair tekniği

\footnotetext{
${ }^{6}$ Bkz. "Dil", Güncel Türkçe Sözlük, erişim Tarihi: 25.02.2015, http://www.tdk.gov.tr/index.
} php?option=com_gts\&arama=gts\&guid=TDK.GTS.54edfc73c8a222.21667433. 
oluşturmaktadırlar. Tıpkı satrançtaki gibi, her bir dil oyununa dahil olmak ona dair tekniği bilmeyi gerektirmektedir. Yine tıpkı satrançtaki gibi oyun ile ilgili eğitildikçe ve oyunu oynadıkça bu tekniklerde ustalaşırız. Dil oyununun tekniklerini onun kurallarının oluşturduğu göz önüne alınacak olursa Wittgenstein'ın "kurala uymak bir pratiktir" (FS, 202) ifadesi daha anlaşılır olur. Wittgenstein aynı alıntıya 'kurala uyma'nın pratik yani edimsel bir şey olmasıyla, onun kişisel olamayacağı arasında bir ilişki kurarak devam eder:

Kurala uyduğunu sanmak kurala uymak değildir. Ve bu yüzden kurala kişisel olarak uyulamaz, çünkü o zaman kurala uyduğunu sanmak kurala uymakla aynı şey olurdu $(F S, 202)$.

Buradaki vurguyu, bir kuralı takip etmenin ancak bir toplum, kültür daha da özel bir ifadesiyle bu dil oyununu oynayan başka kişilerle mümkün olduğu şeklinde değerlendirebiliriz. Wittgenstein'ın FS (243363)'de dile getirdiği "özel dilin olmazlığı" argümanı tam da burada ifade edildiği gibi öznelerarası olmayan bir dilin mümkün olamayacağını dile getirmektedir. Wittgenstein kurala uymak yoluyla bir dil oyununa dahil olmanın sosyal yanını şöyle dile getirir:

Yalnızca bir kişinin, tek bir kez kurala uymuş olması olanaksızdır. Tek bir kez bile iletide bulunulmuş olması, bir emrin tek bir kez verilmiş ya da anlaşılmış olması, vs. olanaksızdır.-Kurala uymak, iletide bulunmak, emir vermek, bir parti satranç oynamak adetlerdir (kullanılagelişler, kuruluşlar) (FS, 199).

Böylelikle kuralı takip etmek bu kuralın kullanılagelişiyle yani bir nevi gelenek ile ilişkilendirilir ve bu kuralların oluşturduğu gramatik bir yapı olarak dil, sosyal olanla daha doğru bir ifadeyle belli yaşam biçimiyle doğrudan ilişkilidir. Gramer ve dil arasındaki ilişkiyi netleştirmek için vurgu yaptığımız bu yaşam biçimini dil ile dilin iç içe örülü olduğu etkinlikler bütünü olarak bir ilişkiler ağıyla açıklayabiliriz. Bu ağ aynı zamanda anlamın kendisine referansla belirlendiği ağdır.

\section{Gramer ve Yaşam Biçimi}

Bir oyunu oynamak nasıl ki o oyunun kuralları hakkında kusursuz bir döküm yapabilmeyi gerektirmiyorsa; bir dili kullanmak, bir dil oyununa dahil olmak da o dil oyununun kuralları ile ilgili benzer bir döküm 
yapabilmeyi gerektirmez. Bu kurallar pratik içerisinde, bir geleneğin parçası olarak, bir yaşam şeklini takip ederek edinilirler. Wittgenstein'a göre biz bir dil oyununa ne onun kuralları hakkında sıkı bir eğitime tabi tutulmak yoluyla dahil oluruz, ne de o dil oyunu içerisindeyken o dil oyunun kurallarına dair bir rehberle hareket ederiz.

Birinin bir oyunu anlamasının işareti nedir? Kuralları sayabiliyor mu olmalıdır? Oyunu oynayabiliyor olması bir kriter midir, mesela oyunu oynayabiliyor olduğu halde kurallar sorulduğunda afallayamaz mı? ...[E]lbette ki açık kurallar olmaksızın oyunu öğrenmek diye bir şey vardır (PG, I, 26).

Dil oyununun kural güdümlü bir faaliyet olduğunu söylemek için bu kuralların dökümünün yapılması şart değildir. Gündelik yaşam içerisinde dil oyununun unsurlarını çok çeşitli biçimlerde kullanabiliriz. Bir ifade, birçok farklı şekilde ve bağlamda kullanılabilir; biz bu ifadenin kullanımına dair tekniklerin bir nevi ustasıyızdır. Bu dil oyunun grameri bu tekniklerin uygun bir şekilde pratiğe dökülüşünün standardını oluştururlar. Bu noktada bir kurala göre hareket etmeyle bir kurala uymak arasında bir ayrım yapmak yerinde olacaktır. Önünde satranç tahtası olan bir bebek, fili çapraz üç kare ileri götürmüş olabilir. Bu durumda bebek kurala göre hareket etmiştir; ancak bu hareket bir kurala uymak manasına gelmez. Kurala uymak bir nedenden hareketle ve yönelimsel olarak bir kurala göre hareket etmek manasına gelir (Baker ve Hacker, 2009:136). Bebek, satranç oyunun kuralına göre uygun bir hamle yapmıştır ancak bu bebeğin bir kurala uyduğunu göstermez çünkü kurala uygun hareketin bir yönelimi olması gerekmektedir. Ayrıca kurala uyma ile bir kurala göre hareket etmek arasındaki bir diğer temel fark da kurala uymanın işlevinde yatar. Kurala uymak aynı zamanda kurallardan oluşan kompleks bir grameri takip etmek manasına gelir. Bir kurala uyduğumuzda bir dil oyunundaki ustalığı sergilemiş oluruz. Satranç örneğini takip edecek olursak, kurala uymak yani bir grameri takip etmek satranç oyunundaki muhtemel hamleler bütününün oluşturduğu kompleks yapıyı düzenlemektedir. Başka bir ifadeyle, satranç kurallarının belirlediği sınırlı yapı içerisinde oldukça kompleks bir hamleler ve oyun kombinasyonu vardır ve bu kurallar bu kompleks bütünü düzenlerler. Bu anlamıla kurala uymak belirli bir kurala göre hareket etmeyi salık veren emir ve buyruklardan farklidir. 
Kurallar genellikle, durumların sınırsız çokluğunu yönettiklerinden ötürü doğaları gereği geneldirler [...] Bu durum gramatik bir önermenin genellik taşıyan bir metalinguistik önerme olması gerektiği manasına gelmez; ancak bir gramatik önermenin verili durum karşısında normatif bir işlevi olması gerektiği manasına gelir (Glock, 1996, s. 324).

Peki, bir kuralı nasıl anlarız ya da bu kuralları nasıl ediniriz? Dil oyunun kurallarının yani gramerinin ne şekilde edinildiğine dair bu sorunun yanıtı aynı zamanda gramerin ne şekilde oluştuğunu da gösterecektir. Wittgenstein'a göre, kuralı bir uzlaşıla ediniriz ve bu uzlaşı zamanla değişen dinamik bir unsurdur. Dolayısıyla uzlaşılarımızla beraber gramerimiz de değişir. Burada sözünü ettiğimiz uzlaşı sözsüz bir uzlaşıdır, Wittgenstein üzerinde uzlaştığımızın yaşam biçimi olduğunu söyler: “...[I]]nsanlar birbirleriyle dilde uyuşurlar. Bu fikirlerin değil, yaşam biçiminin uyuşmasıdır" (FS, 241). Wittgenstein dil kullanan bir varlık olarak insanoğluna doğal tarihimiz içerisinde izini sürebileceğimiz bir ortaklık atfeder ve bunu "ortak insani eylem şekli" $(F S, 206)$ olarak adlandırır. "Emir vermek, sormak, anlatmak, çene çalmak tıpkı yürümek, yemek içmek, oyun oynamak gibi doğal tarihimize aittir" (FS, 25). İnsana dair bu temel yapma etme biçimleri bize özel olarak öğretilmemiştir, ancak biz yaşam biçimine dahil olarak bu ortaklıkların parçası oluruz. Bir yaşam biçimini paylaşmak;

[i்]lgileri ve hissetme yollarını, tepki tarzlarını, mizah anlayışını, önem ve başarı duygusunu, neyin acayip olduğunu, neyin bir diğer şeyle aynı olduğunu, neyin azarlama, neyin affetme olduğunu, bir ifadenin ne zaman varsaymak, ne zaman seslenmek, ne zaman açıklamak olduğu paylaşma meselesidir (Cavell, 1976, s. 52).

Burada söz edilen şey bizim doğal tarihimizdir, her zaman gözümüzün önünde olan ve belki de her daim gözümüzün önünde olduğu için kimsenin kendisinden şüphe etmediği şeydir (FS. 415). Bu yaşam biçimi kavrayışı dilin ne şekilde uzlaşımsal olduğunu anlamamızı sağlayabilir. Yaşam biçimini paylaşmanın uzlaşıma dayandığını söylemek dilin zemininin oldukça sallantılı olarak hissedilmesine yol açabilir. Bunun nedeni uzlaşımı bir sözleşme gibi algılama eğilimimizdir; oysa burada sözünü ettiğimiz uzlaşı bir söze dayanmaz, bu uzlaşı bir şekilde eyleyerek dahil olduğumuz, edimler üzerinde bir uzlaşıdır. "Başlangıçta eylem vardı." (KÜ, 402). 
Wittgensteinbu en temeldeyatanı "temellendirilmemişbireylem tarzı" olarak adlandırır. Dil oyunlarımız, bu yaşam biçiminin bir parçası olarak var olurlar $(F S, 23)$. Ancak insanların ortak ilksel tepkilerde ortaklaştığı bu temel noktadan hareketle evrensel bir gramere sahipmişiz gibi bir sonuç çıkarılmamalıdır; zira gramer belli koşullarda ve yaşam biçimini paylaşan insanların ortak edimleri içerisinde şekillenir. Dolayısıyla, nasıl ki uzlaşımsal olması seçilimsel olması anlamına gelmiyorsa, ortak olması da mutlak olması manasina gelmez.

Böylelikle gramer kurallarının; sosyal ilişkiler içerisinde ortaya çıktıkları için uzlaşımsal, ancak fiili bir durumda görünür oldukları için edimsel, fiili bir durum içerisinde görünür olduklarından ötürü açık bir dökümleri yapılamadığı için örtük, dil oyunlarının sınırlarını belirleyen ve bu dil oyunlarının normlarını ortaya koyan niteliklerinden ötürü normatif olduklarını söyleyebiliriz.

\section{Dilin Otonomisi}

Gramerin altını çizdiğimiz niteliklerinin geç dönem Wittgenstein felsefesi açısından oldukça önemli bir sonucu gramerin otonom olduğu iddiasıdır. Bu iddianın dayandığı üç temel gerekçeyi Glock şöyle özetler: “Gramer bağımsızdır, dil dışı bir gerçekliğe karşı sorumlu değildir ... Gramatik kurallar gerekçelendirilemezler ... Alternatif temsil biçimleri mutlak anlamda irrasyonel değildirler." (Glock, 1996, ss. 45-50).

Gramerin bağımsızliğı yani dil dışı bir gerçekliğe karşı sorumlu olmaması dil ile gerçeklik arasında nasıl bir ilişki olduğuna dair soruyla ilintilidir. Wittgenstein'ın TLP'da ortaya koyduğu yaklaşımın resim kuramı olarak anılmasının nedeni, dilin aynı mantıksal biçimi taşıdığı gerçekliğin bir resmi olduğunun iddia ediliyor olmasıydı (TLP, 6.123, 5.473). Ancak geç döneminde Wittgenstein, bu konudaki görüşü tamamen değişerek gramerin bizim temsil biçimimizi kurduğunu, neyin temsil olarak kabul edileceğini belirlediğini ve gerçekliğe karşı sorumlu olmadığını söylemeye başlar.

$\mathrm{Bu}$ yeni bakış açısına göre gramer kuralları, anlamı takip etmezler, aksine onu kurarlar. Anlam dil dışı bir gerçeklikten hareketle kurulmaz; bilakis dilsel öğeleri belli bir kural uyarınca kullanarak anlamlı hale getiririz. FS'ın henüz ilk değinisinde Augustinus'un dil edinmeyle ilgili savından hareketle eleştirilen dil anlayışı temel olarak, göstererek 
tanımlamaya dayanıyordu. Cavell, bütün dili gösterilen/gösteren, resmedilen/resim ayrımı gibi ontolojik bir kabule dayandıran bu yaklaşımı bir anlam sanrısına kapılmakla eleştirir. Bir temsilin anlamını temsil ettiği şeyde aramak Cavell'a göre, "[k]endini hiçbir şey söylemediği zaman söylemiş, hiçbir şey keşfetmediği zaman keşfetmiş zannetmeye" (Cavell, 1979, s. 221) yol açmaktadır; çünkü bu bakış açısı insanı ve insanın yaşam biçimini dışarıda tutmaktadır. Anlamı dil dışı bir gerçeklikte aramak "transandantal bir yanılsama"dır. Cavell'a göre Wittgenstein'ın temel motivasyonu "insan hayvanını yeniden dilin içine ve böylece felsefeye yerleştirmektir" (Cavell, 1979, s. 206). Wittgenstein bu geçişi “'anlam nedir?' sorusunun yeryüzüne inmesi" olarak tanımlar:

Önce "Anlamın açıklaması nedir?" diye sormanın iki avantajı vardır. Böylece "anlam nedir" sorusu bir bakıma yeryüzüne indirilmiş olur. Zira, elbette, "anlam"ın anlamını anlamak için "anlamın açıklanması"nın anlamını da anlamak gerekir. Kabataslak söylendiğinde: "Anlamın açıklamasının ne olduğunu soralım, zira bunun açıkladığı şey anlam olacaktır." "Anlamın açıklaması" ifadesinin gramerini incelemek size "anlam" sözcügünün grameri hakkında bir şey öğretecek ve sizi "anlam" diyebileceğiniz bir nesne bulmak için çevrenize bakma ayartısından kurtaracaktır (MKK, s. 3).

'Anlam' diyebileceğimiz bir olgu aramak TLP'daki gerçeklik anlayışına işaret etmektedir ve geç dönem Wittgenstein için görüngülerin içini görmek zorundaymışız hissine kapılmak bir hatadır, yapabileceğimiz onların olanaklarına bakmaktır ve bunu da bir gramer incelemesiyle yapabiliriz $(F S, 90)$; çünkü öz gerçeklikte değil gramerde dile gelir (FS, $371)$. Bir şeyin ne tür bir nesne olduğunu söyleyen gramerdir (FS, 373). Dolayısıyla gramer; başka bir referans noktasından hareketle tanımlanacak bir şey değildir; bilakis kendisi başvuru merciidir. Wittgenstein bu durumu şöyle ifade eder: "Gramer herhangi bir gerçekliğe karşı sorumlu değildir. Anlamı belirleyen (onu inşa eden) gramatik kurallardır ve böylelikle gramatik kuralların kendileri herhangi bir anlama karşı mesul değildirler ve bu sayede keyfidirler." (PG, I, 133).

Gramatik kuralların gerekçelendirilememesi dilin nihai olarak dil dışı bir gerçeklikle açıklanamıyor olmasıyla kuşkusuz ki alakalıdır. Ancak bununla sınırlı kalmaz, Wittgenstein'a göre grameri, amacı ve işlevinden hareketle gerekçelendirmek de olanaklı değildir; çünkü gramer amacı ve 
işlevini içerisinde taşır. Bu sebeple amaç ve işlevden hareketle yapılacak her gerekçelendirme denemesi döngüselliğe mahkûmdur. Zettel'de bu durumu şöyle örneklendirir:

Niçin yemek yapma kurallarına keyfi demem ve niçin gramer kurallarına keyfi deme ayartısına kapılırım? Çünkü 'yemek yapma' amacıyla tanımlanır, oysa 'konuşma' öyle değildir. Dil kullanımının, belli bir anlamda, yemek yapmanın ve yıkamanın özerk olmaması gibi, özerk olması bu yüzdendir. Yemek yaparken sizi doğru kurallar değil de başka kurallar yönlendirirse, kötü yemek yaparsınız; oysa satranç kurallarından başka kurallar izlerseniz, başka bir oyun oynuyor olursunuz; ve şu şu gramer kurallarından başka gramer kurallarını izlerseniz, bu sizin yanlış bir şey söylediğiniz anlamına gelmez, hayır, başka bir şeyden söz ettiğiniz anlamına gelir $(Z, 320)$.

Yemek yapmanın amacı ortaya çıkacak olan şey, yemektir ve dolayısıyla etkinliği bu amaçtan hareketle gerekçelendirebiliriz çünkü bu amacın ortaya çıan etkinliğin kurucusu olduğunu söyleyebiliriz. Ancak grameri ortaya çıkan etkinlikten hareketle gerekçelendiremeyiz. Bunun için dilin amacının ne olduğunu sormamız gerekir çünkü gramerin ortaya çıkardığı bir dildir. Bu durumda dilin amacı olarak, dilsel etkinliğin sonucu yani 'iletişim' tanımlanabilir; ancak dilin kurallarını iletişim gibi bir amaçtan hareketle de gerekçelendiremeyiz çünkü dil ve iletişim arasında araçsal değil kavramsal bir ilişki vardır. İletişim amacını yerine getiremeyen bir ses ya da simge dizgesine kötü bir dil diyemeyiz; o bir dil değildir.

Bir gramerin gerekçelendirilmesi bir önermenin kanıt olarak sunulmasıyla gerçekleştirilebilir ancak bu önerme de bir dil içerisinde ve dolayısıyla bir gramatik çerçeve içerisinde ifade edilmiştir. Herhangi bir gramere dahil olmayan, kavramsal perspektife aşkın ve dil dışı bir zemin yoktur. Bu durum grameri amacı ya da işlevinden hareketle gerekçelendirmeye çalışan kişiyi bir ikilemle karşı karşıya getirir. Ya gramatik kuralı kendi gramatik çerçevesiyle aynı çerçeveye sahip bir önermeyle gerekçelendirmek gerekmektedir ya da farklı bir gramatik çerçeveye sahip bir önermeden hareket etmek gerekmektedir. İlk durumun sonucu fasit bir daire, ikinci durumun ki eşölçülemezlik olacaktır.

Alternatif temsil biçimlerinin mutlak anlamda irrasyonel olmayacağ 
fikri temel olarak Wittgenstein'ın, grameri, ifadelerin uygun bir şekilde kullanılıp kullanılmadığını belirlememize yarayan bir 'yöntem' bir 'temsil biçimi' olarak tanımlamasından kaynaklanır (Glock, 1996:129). Ancak burada gözden kaçırılmaması gereken, gramerin bize sağladığının belirli bir temsil değil, temsil biçimi olduğudur. Belirli bir temsil 'doğru' ya da 'yanlış' olabilirken bir temsil biçimi ancak 'kullanışlı' ya da 'kullanışsız' olarak nitelenebilir. Başka bir ifadeyle, temsil biçimi bize temsile dair tüm mümkün uzayı sunar. "Bir gramatik sistemin reddi bir uzunluk ölçüm standardının reddi gibidir ve bir gramatik sistemin, bir sembolizmin kabulü bir uzunluk ölçüm standardının kabulü gibidir" (WL II, s. 69). Wittgenstein burada bir hipotezi reddetmenin, 'doğru' ya da 'yanlış' olabileceğini; ancak bir sembolizmi yani gramatik sistemi reddetmenin, 'kullanışlı' ya da 'kullanışsız' olabileceğini vurgular ve ona göre hiçbir "sembolizm zorunlu değildir" (WL II, 22).

Wittgenstein doğa olguları ve kavramlar arasındaki ilişkiden bahsederken, doğa olguları alışılageldiğinden farklı tahayyül edildiğinde, alışılmıştan farklı kavram oluşumlarının anlamlı hale geleceğini söyler (FS, s. 249). Dilini, yaşam şeklini, coğrafyasını hiç bilmediği bir kabile ile ilgili araştırma yapmaya giden bir antropolog varsayalım. Bu antropolog bir süre sonra kabilenin dilini öğrenmeye başladığında bu kabilenin renkler ve şekiller için iki ayrı kavram setine sahip olmadıklarını fark edebilir mi? Ya da daha doğru bir ifadeyle, renkler ve geometrik şekillerin aynı kavram seti içersinde ele alınması mümkün müdür? Wittgenstein'a göre böyle bir durum tabi ki mümkündür: “O zaman, kırmızı, yeşil ve yuvarlak bir araya getirilebilir mi? -Niçin olmasın?!" (Z, 331).

$\mathrm{Bu}$ örneğe şekil ile renk arasındaki farklara vurgu yapılarak karşı çıkılabilir. Örneğin denilebilir ki, yuvarlak, iki boyutlu bir uzayda bir noktaya eşit uzaklıktaki noktaların kümesine denir, ancak renk bu niteliklere sahip değildir, bu sebeple renk ve yuvarlak ayn kavram seti içerisinde değerlendirilemez. Ya da renk, geometrik bir şekil gibi köşeye kenara sahip değildir, o yüzden renk ve geometrik şekiller bu örnekteki gibi aynı kavram seti içerisinde değerlendirilemezler. Bu iki karşı çıkışta da gözden kaçan önemli husus gramerin anlamın belirleyicisi olduğu hususudur. Rengin, şeklin, hatta renk ve şekil arasındaki farkın anlamı gramer tarafından belirlenir, kavramların anlamını belirleyen gramere aşkın bir düzlem yoktur. "Nesnenin doğasına ilişkin bir zorunluluğun dildeki tek bağlaşığı, keyfi bir kuraldır." (FS, 372). Böylelikle farklı bir gramatik sistem yani farklı bir sembolizm mümkün hale gelir.

\section{Sonuç}


Wittgenstein 1929 yılında yazdığı bir notta felsefede izlediği yöntemi "hakikat sorusunu bırakıp onun yerine anlamı sormak" olarak tanımlar (KD, MS 105 46c:1929). Kuşkusuz ki buradaki anlam, mantığın kristal saflığı aracılığıyla dil ile resmedilen olgular değil; dilin kullanımında kendini gösteren yeryüzüne inmiş olan anlamdır. ${ }^{7} \mathrm{Bu}$ değişimde olgular, pratikle şekillenen yaşam biçimiyle; mantığın kristal saflığ 1 ise temsil biçimlerimizi şekillendiren gramerle yer değiştirir. Bu değişimin arkasında dil ile gerçeklik arasında kurulan ilişkinin keskin bir şekilde değiştirilmesi yatar. Dil artık anlamını resmi olduğu gerçeklikte bulan bir yapı değil; bilakis anlamını kullanımından alan otonom bir yapıdır. Dil bu otonomisini anlamı belirleyen temsil sistemimizin yani gramatik yapının keyfiliğinden alır; ancak bu keyfilik gramerin bireysel seçime dayanması, kolayca değiştirilebilmesi, sıklıkla değişmesi ya da önemsiz olması manasına gelmez. Gramerin keyfi olmasıyla ifade edilmeye çalışılan, gramerin kendi dışındaki bir gerçekliğe referansla doğru ya da yanlış olamayacağıdır. Dilin sınırını artık, dünya değil, içerisinde var olduğu insansal pratikler yani yaşam biçimi oluşturur. Dolayısıyla anlamı hedefleyen bir soruşturma, mantıksal bir soruşturmadan ziyade yaşam biçimi etrafında şekillenen antropolojik bir soruşturma olacaktır. Nitekim Wittgenstein da "Sraffa'yla konuşmakla kazandığı en önemli şeyin felsefi sorunlara 'antropolojik' bir yönden bakmak" olduğunu söyler (Monk, 2005, s. 378).

Wittgenstein'ın Kendi Eserlerine Verilen Referanslarda Kullanılan

Kisaltmalar

Defterler 1914-1916

Defterler

Felsefi Soruşturmalar

FS

Kesinlik Üzerine

$K \ddot{U}$

Kültür ve Değer

$K D$

Mavi Kitap Kahverengi Kitap

$M K K$

Philosophical Remarks

$P R$

Philosophical Grammar

$P G$

Remarks on the Foundations of Mathematics

RFM

Tractatus Logico-Philosophicus

TLP

Wittgenstein's Lectures: Cambridge 1930-1932

WL I

Wittgenstein's Lectures: Cambridge 1932-1935

WL II

Zettel

Umut Morkoç, Ege Üniversitesi, Türkiye

7 Bkz. $(F S, 106)$ ve $(M K K$, s.3). 


\section{Kaynakça}

Baker, G. ve Hacker P. M. S. (2009). Wittgenstein Rules, Grammar and Necessity. Wiley-Blackwell, Singapore.

Cavell, S. (1976). Must We Mean What We Say? Cambridge University Press, Cambridge, New York, Melbourne.

Cavell, S. (1979). The Claim of Reason: Wittgenstein, Skepticism, Morality and Tragedy. Oxford University Press: Oxford.

Foster, Michael, N. (2004). Wittgenstein on The Arbitrariness of Grammar. Princeton University Press: Princeton, Oxford.

Glock, H. J.(1996). A Wittgenstein Dictionary. Blackwell Publishers, Oxford.

Malcolm, N., Georg Henrik von Wright. (1984). Ludwig Wittgenstein: A Memoir. Oxford University Press: USA

Monk R. (2005). Ludwig Wittgenstein: Dahinin Görevi. Çev. Berna Kılınçer, Tülin Er. Kabalcı Yayınları: İstanbul.

Wittgenstein, L. (1978). Philosophical Grammar. Ed. Rush Rhess. Çev.Anthony Kenny. University of California Press: Berkeley, Los Angeles.

Wittgenstein, L. (1978). Remarks on the Foundations of Mathematics. Ed. G. H. Wright, R, Rhees, G.E.M. Anscombe. İng. Çev. G. E. M. Anscombe. MIT Press: Cambridge. Massachusetts, London.

Wittgenstein L. (1979). Wittgenstein's Lectures: Cambridge 1932-1935. Ed. Alice Ambrose. Basil Blackwell: Oxford.

Wittgenstein L. (1982). Wittgenstein's Lectures: Cambridge 1930-1932. Ed. D. Lee, University of Chicago Press: Chicago.

Wittgenstein L. (1989). Lectures on Foundations of Mathematics. Ed. Cora Diamond. Cornell University Press: New York.

Wittgenstein, L. (2004). Defterler. Ed. G. H. von Wright, G. E. M. Anscombe. Çev. Ali Utku. Birey Yayıncılık: İstanbul.

Wittgenstein, L. (2004). Zettel. Çev. Doğan Şahiner. Nisan Yayıncılık: İstanbul.

Wittgenstein, L. (2005). Tractatus Logico-Philosophicus. Çev. Oruç Aruoba. Metis Yayınları: İstanbul.

Wittgenstein, L. (2007). Felsefi Soruşturmalar, Çev. Haluk Barışcan. Metis Yayınları: İstanbul.

Wittgenstein, L. (2007). Mavi Kitap Kahverengi Kitap. Çev. Doğan Şahiner, İş Bankası Kültür Yayınları: İstanbul.

Wittgenstein, L. (2009). Kesinlik Üzerine + Kültür ve Değer. Çev. Doğan Şahiner. Metis Yayınları: İstanbul. 